\title{
Mathematical Problem-solving: Students' Cognitive Level for Solving HOTS Problem in Terms of Mathematical Ability
}

\author{
Chairul Anami ${ }^{1, *}$ Budi Usodo ${ }^{2}$ Sri Subanti ${ }^{3}$ \\ ${ }^{I}$ Postgraduate of Mathematics Education, Faculty of Teacher Training and Education, Sebelas Maret University \\ Surakarta, Indonesia \\ ${ }^{2,3}$ Faculty of Teacher Training and Education, Sebelas Maret University Surakarta, Indonesia \\ *Corresponding author. Email: anamichairul22@student.uns.ac.id
}

\begin{abstract}
Higher-order thinking skills (HOTS) have an essential role for students, especially in the 21 st century. HOTS is seen as a basic ability that must be developed, especially in learning mathematics. Problem-solving ability is one of the basic abilities that students must have. Problem-solving ability is one of the highest HOTS levels by combining creative thinking and critical thinking. The purpose of this study was to analyze the students' highest cognitive level in solving HOTS problems. This research is included in the form of descriptive qualitative research. The subjects of this study were 29 students of class VII MtsN 9 Banjar who had heterogeneous ability levels, namely high, medium and low mathematical abilities. However, this article only presents data from three subjects that represent Heterogeneous ability. Several data collection techniques in this research, namely the HOTS problem-solving test and semi-structured interviews. Data analysis techniques include data reduction, data presentation, and conclusion or verification. The validity of the data is obtained through validation and triangulation. The results of this study conclude that students with high mathematical abilities can reach the cognitive level of C6 (creating) in solving HOTS problems, while students with moderate mathematical abilities can reach the highest cognitive level of C5 (Evaluating) in solving HOTS problems, then for students with mathematical abilities. Low can reach the highest cognitive level C4 (analyze) in solving HOTS problems.
\end{abstract}

Keywords: Cognitive Level, HOTS, Problem-Solving.

\section{INTRODUCTION}

High Order Thinking Skill (HOTS) has an essential role for students, especially in the $21 \mathrm{st}$ century [1]. HOTS is thinking that is more than just remembering facts that emphasize applying the information to construct knowledge [2-4]. HOTS is a thinking process that requires students to manipulate existing information and ideas in a certain way that gives them new understanding and implications in solving everyday problems [5-7]. For example, when students combine facts and ideas in the process of synthesizing, generalizing, explaining, conducting hypotheses, and analyzing to conclude [8]. HOTS is thinking that is more comprehensive and complex with the aim of obtaining solutions to problems.

HOTS includes the ability to analyze (C4), evaluate (C5), and create (C6) $[9,10]$. HOTS indicators in Bloom's taxonomy are presented in Table $1[11]$.

Table 1. HOTS Indicators in Revised Bloom's Taxonomy.

\begin{tabular}{|c|c|c|}
\hline Indicator & Sub Indicator & $\begin{array}{c}\text { Knowledge } \\
\text { Object }\end{array}$ \\
\hline Analyze (C4) & $\begin{array}{l}\text { Differentiate } \\
\text { Organize } \\
\text { Attribute }\end{array}$ & \multirow{3}{*}{$\begin{array}{c}\text { Conceptual } \\
\text { Procedural } \\
\text { Metacognitive }\end{array}$} \\
\hline Evaluate (C5) & $\begin{array}{l}\text { Check } \\
\text { Criticize }\end{array}$ & \\
\hline Create (C6) & $\begin{array}{l}\text { Formulate } \\
\text { Plan } \\
\text { Produce }\end{array}$ & \\
\hline
\end{tabular}


Thus, higher-order thinking ability (HOTS) is the ability to think more than remembering facts and emphasizing meaning to obtain solutions to problems by analyzing, evaluating, and creating. $[10,12]$.

Mathematical problem solving has a crucial role in the development of students' thinking skills [13]. Problem-solving abilities can develop students' thinking skills [14]. Problem-solving ability is one way to develop higher-order thinking skills [15]. Problem-solving ability is one part of HOTS ability [16]. Problem-solving is the highest level of HOTS by combining creative thinking and critical thinking. Thus, it can be concluded that problem-solving can develop students' thinking skills, especially HOTS abilities [17].

Problem-solving in this study is a problem-solving model presented by Polya. Problem-solving is an attempt to find a way out of a difficulty to achieve a goal that is not immediately achievable [18]. There are four stages of problem-solving presented by Polya, namely 1) understanding the problem, 2) devising a plan, 3) carrying out the plan, and 4) looking back [19, 20]. he Polya Problem Solving Stage Indicators are presented in Table 2.

Table 2 . Polya. Problem-Solving Stages

\begin{tabular}{|c|c|c|}
\hline No. & Problem Solving Stage & Indicator \\
\hline 1. & Understanding the Problem & $\begin{array}{l}\text { 1. Students can write down what is known and what is asked. } \\
\text { 2. Students can explain the problems that exist in the } \\
\text { problem in their sentences. }\end{array}$ \\
\hline 2. & Devising a plan & $\begin{array}{l}\text { 1. Students can write appropriate examples from the } \\
\text { information known in the problem. } \\
\text { 2. Students can write the appropriate formula between what } \\
\text { is known and what is asked to solve the problem. }\end{array}$ \\
\hline 3. & Carrying out the plan & $\begin{array}{l}\text { 1. Students can substitute the information correctly into a } \\
\text { predetermined formula. } \\
\text { 2. Students can perform the necessary calculations to support } \\
\text { the correct answers to questions. } \\
\text { 3. Students can write down the steps of completion } \\
\text { coherently and correctly. }\end{array}$ \\
\hline 4. & Looking Back & $\begin{array}{l}\text { 1. Students can write their own way of re-examining the } \\
\text { results of the work using the known elements in the } \\
\text { problem. } \\
\text { 2. Students can write the conclusion of the solution. }\end{array}$ \\
\hline
\end{tabular}

Several studies on higher-order thinking skills by applying the Polya stages have been carried out. The difficulty of solving mathematical problems for elementary school students in solving story questions includes understanding problems, determining mathematical formulas/concepts to be used, making connections between mathematical concepts, and reviewing the truth of answers to questions [15]. Learning mathematics with problem-solving can develop students' critical thinking skills because each stage in problem-solving requires students' critical thinking skills [21]. Other efforts that can make to develop students' HOTS abilities are:
1. Involving students in non-routine problemsolving activities

2. Facilitating students to develop analytical and evaluating skills (critical thinking) and creative abilities (creative thinking)

3. Encourage students to construct their knowledge, so that learning becomes meaningful for students [22].

Based on previous research related to HOTS and problem solving, it can be concluded that research related to problem-solving has been carried out in solving story problems, but to find out the highest cognitive level of students in solving HOTS-based 
mathematical problems has not been carried out. Therefore, the researcher considers it necessary to conduct research related to students' ability to solve HOTS problems in terms of problem solving and as a form of literature contribution about solving HOTSbased mathematical problems given to students. The purpose of this research is to analyze the students' highest cognitive level in solving HOTS problems in high, medium, and low ability students.
His research is descriptive qualitative research. Descriptive research is conducted to describe or explain systematically, factually, and accurately the facts and characteristics of a particular population [23]. Research describes the data in absolute terms without any manipulation [24]. The subjects of this study were 29 students of class VII MtsN 9 Banjar who had heterogeneous ability levels, namely high, medium and low mathematical abilities. The distribution and category of subject HOTS problemsolving abilities are presented in Table 3.

\section{RESEARCH METHOD}

Table 3. Category and distribution of HOTS problem-solving abilities

\begin{tabular}{|l|c|c|c|}
\hline $\begin{array}{c}\text { Mathematical Ability } \\
\text { Level }\end{array}$ & Formula & Interval & The Number of students \\
\hline Tall & $s>\bar{x}+S D$ & $s>77.4+14$ & 5 \\
\hline Currently & $\bar{x}-S D \leq s \leq \bar{x}+S D$ & $77.4-14 \leq s \leq 77.4+14$ & 17 \\
\hline Low & $s<\bar{x}-S D$ & $s<77.4-14$ & 7 \\
\hline \multicolumn{2}{|c|}{ Total } \\
\hline
\end{tabular}

Information :

$s=$ Student Score

$\bar{x}=$ Average Value

$S D=$ Standar Deviation

However, this article only presents data from three subjects on students with high, medium, and low mathematical abilities. The characteristics of the research subjects are students who have studied the material on integers and students who can convey ideas in writing.

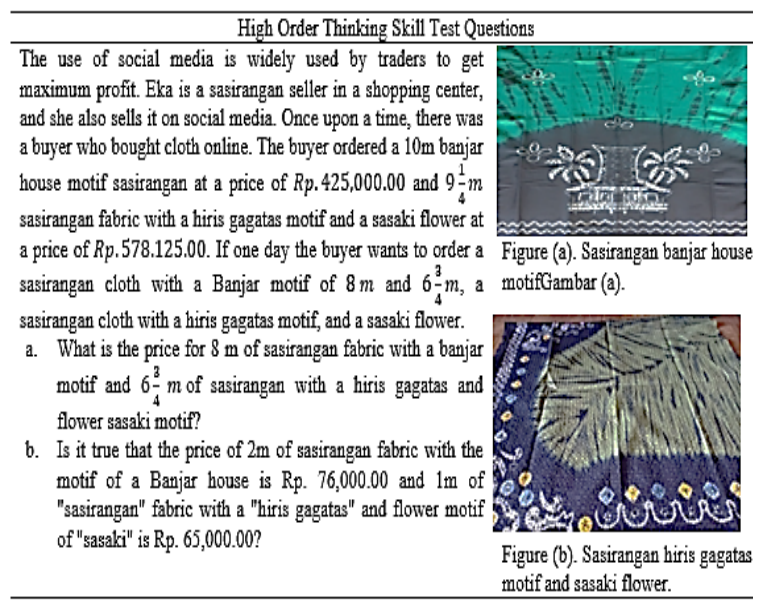

Figure 1 HOTS. mathematical problems

This study using instruments namely the HOTS test instrument and interviews to obtain information from students, this instrument related to problemsolving abilities. The test is in the form of a description question with HOTS ability indicators. The instrument was validated by one lecturer of Mathematics education at UIN Antasari Banjarmasin and one mathematics teacher from MtsN 9 Banjar. Revisions were made to improve the quality of the instrument, namely by adding images of different motifs of sasirangan cloth, adding instructions on how to do the questions, and clarifying the sentences on the questions so that students easily understand them. The HOTS mathematical problem is presented in Figure 1.

The study identified the cognitive level of students in solving HOTS problems. Thus the answer guidelines or problem rubrics need to accommodate the cognitive level. The guidelines are presented in Table 4.

Data collection techniques were used in this study, namely the HOTS problem-solving test and semistructured interviews [25]. The test is a tool or procedure to collect information and measure student success [26]. In this study, the test method was used to explore students' HOTS problem-solving data. The interview is a technique or procedure to obtain answers based on one-sided questions and answers with respondents [26]. Interviews were used to dig deeper into students' HOTS problem-solving. The material presented on the test is integers. The data in this study were used to determine how the cognitive level of students' HOTS in terms of students' ability to solve HOTS problems.

The research was analyzed through three stages, namely data reduction, data presentation, and conclusion or verification [27]. The triangulation 
carried out in this research is technical triangulation, which obtains data from the same source with different techniques $[24,25,27]$, namely comparing the data obtained through test and interview methods [28].

Table 4. Guidelines for answers based on the HOTS cognitive level

\begin{tabular}{|c|c|c|}
\hline Level & Description & Answer Stage \\
\hline C4 & $\begin{array}{l}\text { Cognitive level C4 is Analyzing because this } \\
\text { question uses the actual stimulus and measures } \\
\text { the cognitive level of students' reasoning. In this } \\
\text { problem, students are expected to distinguish } \\
\text { data that is correlated or related to the solution } \\
\text { and classify data in solving problems by } \\
\text { separating different data. }\end{array}$ & $\begin{array}{l}\text { In this problem, students are asked to find the } \\
\text { price per meter of sasirangan banjar house motif, } \\
\text { sasirangan with hiris gegatas motif fabric, and } \\
\text { flower sasaki with their skills in processing } \\
\text { fractions. Then the results obtained are two types } \\
\text { of prices, so students are required to be able to } \\
\text { distinguish the appropriate part and the part that } \\
\text { does not match what is known in the problem. }\end{array}$ \\
\hline C5 & $\begin{array}{l}\text { Cognitive level } \mathrm{C} 5 \text { is evaluating because this } \\
\text { includes the ability to re-examine the statement } \\
\text { on the problem. }\end{array}$ & $\begin{array}{l}\text { In this question, students are asked to re-examine } \\
\text { the statements given. Students must find the part } \\
\text { that corresponds to what is asked in the problem. } \\
\text { Students must be able to find the accuracy of a } \\
\text { procedure in solving problems. }\end{array}$ \\
\hline $\mathrm{C} 6$ & $\begin{array}{l}\text { The cognitive level is creating because this } \\
\text { problem includes the stage of determining } \\
\text { methods in solving problems and making } \\
\text { decisions, concluding and providing new } \\
\text { solutions. }\end{array}$ & $\begin{array}{l}\text { In this question, students are asked to conclude } \\
\text { the results of the answers that have been done, } \\
\text { then students provide new solutions by reworking } \\
\text { the questions given differently. }\end{array}$ \\
\hline
\end{tabular}

\section{RESULT}

The research results are data tested using a test instrument in the form of a description of one HOTS question associated with solving mathematical problems on integer material. After the HOTS test questions were tested on three research subjects, namely students with high abilities (SFZ), students with moderate abilities (BD), and students with low abilities (APP), the researchers found an overview of students' cognitive abilities in solving HOTS problems. The research results will be presented as follows.

\subsection{Subject SFZ}

From Figure 2 and Figure 3. The SFZ answer sheet that has been presented can be seen that SFZ has good problem-solving abilities. In addition, SFZ is also classified as a student who can reach the highest cognitive level, namely the C6 cognitive level (creating). SFZ can solve the given problem based on the problem-solving steps, according to Polya.

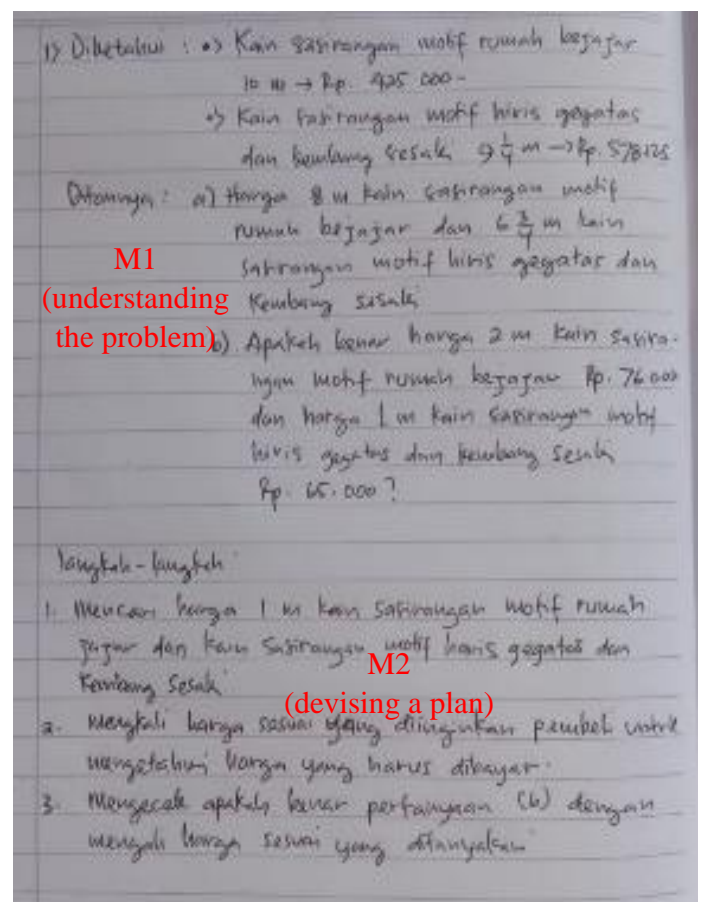

Figure 2 Answer sheet 1 student SFZ 


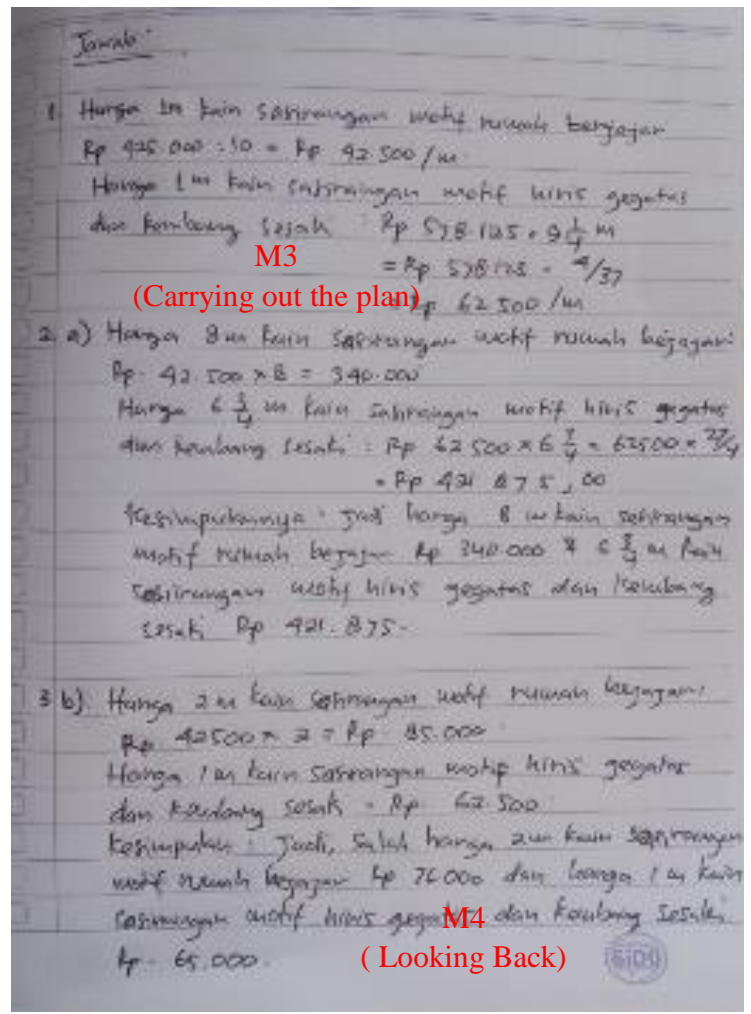

Figure 3 Answer sheet 2 student SFZ

The following is a description of the data obtained based on the answer sheet sent by SFZ, as follows:

1. M1 (understanding the problem)

SFZ can determine what information is known and asked from the questions given at the stage of understanding the problem. Based on the picture, the results of SFZ's work in solving the HOTS problem, it can be seen that SFZ has understood the problem correctly. It is evidenced by the answer given by SFZ that what is known from the question is the price of the sasirangan cloth with the motif of a Banjar house $10 \mathrm{~m}=$ $R p .425,000.00$ and the price of the sasirangan cloth with the hiris gagatas and flower sasaki motifs $9 \frac{1}{4} m=R p .578,125.00$. Then what was asked about the price of $8 \mathrm{~m}$ of sasirangan cloth with a banjar motif and $6 \frac{3}{4} \mathrm{~m}$ of sasirangan cloth with hiris gagatas and flower motifs? Is it true that the price of $2 \mathrm{~m}$ of sasirangan cloth with a banjar motif is $R p .76,000$ and the price of $1 \mathrm{~m}$ of sasirangan cloth with hiris gagatas and motifs. Flower sasaki $R p .65 .000$. Thus, in the activity of understanding the problem, it can be seen that SFZ is able to understand the problem from the questions given. kembang sasaki $9 \frac{1}{4} m=$ Rp. 578.125,00.

2. M2 (Planning The Problem)

When planning the problem, SFZ can develop strategies to answer what is known and what is asked from the questions. Based on the SFZ answer sheet, SFZ can estimate what to look for first. This is evidenced by the answer submitted by SFZ that SFZ wrote down the steps to solve the problem. Thus, in the problem planning activity, it can be seen that SFZ can plan problems from the questions given.

3. M3 (carrying out the plan)

At the stage of implementing the plan, SFZ can work according to the plan that has been made, SFZ solves the problem with the strategy that has been made. This is evidenced by the answer given by SFZ that to find out the price of $1 \mathrm{~m}$ of sasirangan fabric with Banjar motifs and sasirangan with "hiris gagatas" and flower "sasaki" motifs. SFZ divides the prices known in the problem, namely the price of $1 \mathrm{~m}$ of sasirangan fabric with a Banjar motif $=\frac{425,000}{10}=$ $42,500,1 \mathrm{~m}$ of sasirangan fabric with a hiris gagatas motif, and a sasaki flower $=578,125 \div$ $9 \frac{1}{4} m=578,125 \times \frac{4}{37}=62,500$. Then multiply the price obtained to check the truth stated in the problem.

4. M4 (Looking Back)

In the re-examination stage, SFZ writes conclusions according to the questions that have been given, then SFZ does the re-calculation differently. SFZ using a comparison method that aims to ensure the correctness of the answers that have been done, as shown in Figure 4 below:

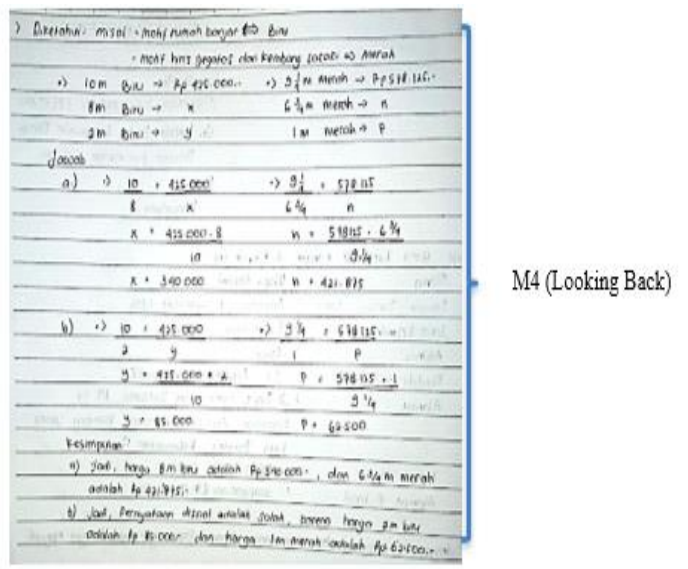

Figure 4 SFZ answer sheet at the re-examination stage.

Based on Figure 4, the results of SFZ's work at the re-examination stage. SFZ can prove that the final result of his work is correct. This is evidenced by SFZ re-proving using a comparison method and the results of the answers calculated by SFZ using the same comparison as the results using the integer calculation method so that the answer can be declared correct. SFZ can determine how much $8 \mathrm{~m}$ of sasirangan cloth with 
the Banjar house motif and $6 \frac{3}{4} \mathrm{~m}$ of sasirangan fabric with Hiris gegatas and flower sakaki motifs, as well as the price for $2 m$ of sasirangan fabric with a Banjar motif and $1 \mathrm{~m}$ of sasirangan fabric with hiris gegatas and flower motifs of sakaki.

The results of the analysis of written answers show that SFZ can bring up the four stages of problemsolving according to Polya, namely understanding the problem, planning a plan, implementing the plan, and checking again.

Therefore, to explore the ability of SFZ in solving HOTS problems, interviews were conducted between researchers and SFZ, which are described below:

$\mathrm{P} \quad$ : After you read the questions given. Do you understand the matter?

SFZ : Yes, I understand, ma'am.

$\mathrm{P} \quad$ : After you understand the question. What do you know from the questions given?

SFZ : What is known from the questions given is that the price of the sasirangan cloth with the motif of a Banjar house is $10 m=R p .425,000.00$, and the price of the sasirangan cloth with the hiris gagatas and flower sasaki motifs is $9 \frac{1}{4} m=R p .578 .125 .00$.

$\mathrm{P} \quad$ : Then what is asked in the question?

SFZ : What was asked from the question, namely the price of $8 \mathrm{~m}$ of sasirangan fabric with a Banjar motif and $6 \frac{3}{4} \mathrm{~m}$ of sasirangan fabric with hiris gagatas and flower motifs of sasaki, is it true that the price of $2 m$ of sasirangan fabric with a Banjar motif is Rp. 85,000 and the price of $1 \mathrm{~m}$ of sasirangan fabric with a motif of sliced gagatas and flower sasaki Rp. 65,000.

$\mathrm{P} \quad$ : How do you plan to solve the problems given?

SFZ : First, I'm looking for the price of $1 \mathrm{~m}$ of sasirangan fabric with the motif of the Banjar house and the sasirangan fabric with the hiris gagatas and flower sasaki motifs. Second, multiply the price that has been obtained to find out the price that the buyer must pay. Third, examine the statement of the question in point (b) by multiplying the price according to what was asked.

P : Did you finish according to the plan that you have made?

SFZ : Yes, ma'am, I completed the questions given according to the plan I had made.

$\mathrm{P} \quad$ : Are you sure about the answers you have done?
SFZ : Insya Allah, I'm sure, ma'am. I also tried to use other ways to find out if the answer I was working on was correct or not. Here I use another method, namely by using a comparison method.

P : Based on the solutions you got, what can you conclude from the questions given?

SFZ : In conclusion, the price of $8 \mathrm{~m}$ of sasirangan fabric with a banjar motif is 340,000 and $6 \frac{3}{4} \mathrm{~m}$ of sasirangan fabric with hiris gagatas and flower sasaki motifs is 421,875. And the price of $2 m$ of sasirangan fabric with a banjar motif is 76,000 and $1 m$ of sasirangan fabric with hiris gagatas and flower sasaki motifs is 65,000

Based on student answers and interviews, it can be said that students who have the ability to solve HOTS problems until they reach the highest level of cognitive C6 (Creating) and can apply all problem-solving skills according to Polya, namely understanding problems, planning problems, implementing plans and reexamining.

\subsection{Subject BD}

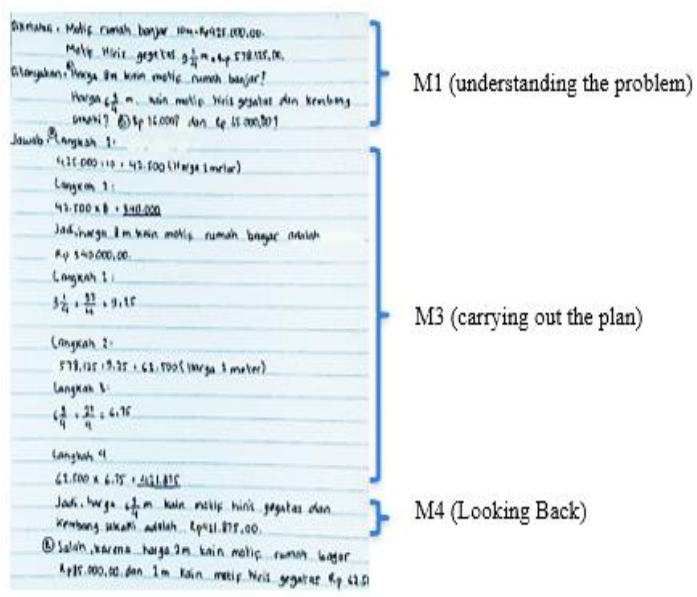

Figure 5 Answer sheet student BD

From Figure 5. BD's answer sheet has been presented, and it can be seen that $\mathrm{BD}$ has poor problem-solving abilities. In addition, BD is also classified as a student who can reach the highest cognitive level C5 (evaluating). According to Polya, $\mathrm{BD}$ has not been able to solve the problems given based on the problem-solving steps. The following is an explanation of the data obtained based on the answer sheet sent by BD, as follows:

1. M1 (Understanding the Prolem)

At the stage of understanding the problem, BD can determine the known and asked information 
from the questions given. Based on the picture of BD's work in solving the HOTS problem, it can be seen that $\mathrm{BD}$ has understood the problem correctly. This is evidenced by the answer given by $\mathrm{BD}$ that what is known from the question is the Banjar house motif $10 m=R p .425,000$ and the hiris gagatas and flower sasaki motifs $9 \frac{1}{2} m=R p \cdot 578,125$. Then what was asked from the question was the price of $8 \mathrm{~m}$ of Banjar house motif cloth, $6 \frac{3}{4} m$ of hiris gagatas and flower sasaki motifs, and 76,000? And 65,000? Thus, in the activity of understanding the problem, it can be seen that BD can understand the problem from the questions given.

2. M2 (Planning The Problem)

At the stage of planning the problem, BD does not develop strategies to answer what is known and asked from the questions. Based on BD's answer sheet, BD did not plan what to look for in advance.

3. M3 (carrying out the plan)

At the stage of implementing the plan, BD immediately performs calculations, namely looking for the price of $1 \mathrm{~m}$ of sasirangan fabric with a Banjar motif of $425,000 \div 10 \mathrm{~m}=$ 42,500 and multiplying the price that has been obtained $42,500 \times 8=340,000$. And looking for $1 \mathrm{~m}$ of sasirangan cloth with hiris gagatas and flower sasaki $578.125 \div 9.25=62.500$ and multiplying the price obtained $62.500 \times$ $6.75=421.875$. Then check the price of $2 \mathrm{~m}$ of Banjar house motif fabric and $1 \mathrm{~m}$ of gegatas hiris motif fabric.

4. M4 (Looking Back)

At the stage of re-checking the results of the truth that $\mathrm{BD}$ has done, $\mathrm{BD}$ does not write down all the conclusions from the questions that have been given, and BD does not recalculate in a different way. Furthermore, to clarify the ability of BD in solving HOTS problems by conducting interviews. From the results of the analysis of written answers, it shows that BD can bring up several stages of problem-solving according to Polya, namely understanding the problem, implementing the plan.

Therefore, to explore BD's ability to solve HOTS problems, interviews were conducted between researchers and $\mathrm{BD}$, which are described below:

$\mathrm{P} \quad$ : Do you understand the questions given?

BD : Yes, I understand, ma'am.

$\mathrm{P}$ : After you understand the questions given. What do you know from the questions given?

$\mathrm{BD}$ : What is known from the question about the motif of the Banjar house is $10 \mathrm{~m}=$
Rp.425.000 and the motif of hiris gegatas is $9 \frac{1}{4} m=R p .578 .125$.

$\mathrm{P} \quad$ : Then what is asked from the question?

$\mathrm{BD}$ : What is being asked from the question, namely the price of $8 \mathrm{~m}$ of Banjar house motif fabric, the price of $6 \frac{3}{4} m$ of hiris gagatas and flower sasaki motifs and 76.000?And 65.000?

$\mathrm{P} \quad$ : How do you plan to solve the problems given?

$\mathrm{BD}:$ I didn't write down the strategy or plan to solve the given problem, but I immediately solved the given problem.

$\mathrm{P} \quad$ : Are you sure about the answers you have done?

BD : Insya Allah, I'm sure, ma'am.

$\mathrm{P} \quad$ : Based on the solutions you got, did you make any conclusions from the results you have done?

BD : ot all, ma'am. Only point a uses the conclusion, namely the price of $8 \mathrm{~m}$ of Banjar house motif cloth is Rp. 340.000 and the pricea $6 \frac{3}{4} m$ of hiris gegatas and flower sasaki cloth is Rp.421.875. For point $b$, I forgot to draw the conclusion.

Based on the results of student answers and interviews, it can be concluded that students who have low mathematical abilities are less able to solve HOTS problems, and at the Polya problem-solving ability stage, the subject can apply several Polya stages, namely understanding the problem, making plans and Looking Back. But unable to make plans.

\subsection{Subject APP}

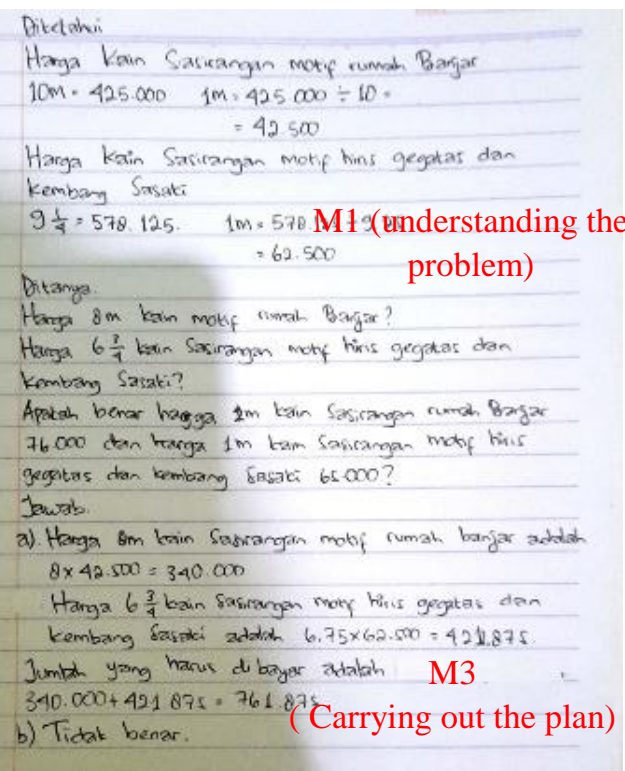

Figure 6 Answer sheet student APP 
From Figure 6. APP's answer sheet has been presented, and it can be seen that APP has poor problem-solving abilities. In addition, APP is classified as a student who reaches the highest cognitive level C4 (analyzing). According to Polya, APP has not been able to solve the problems given based on the problem-solving steps. The following is a description of the data obtained based on the answer sheet sent by APP, as follows:

1. M1 (Understanding the problem)

APP can determine what information is known and asked from the questions given at the stage of understanding the problem. Based on the results of APP's work in solving the HOTS problem, it can be seen that APP has understood the problem correctly. This is evidenced by the answer written by APP that what is known from the question is the price of the sasirangan fabric with the motif of the Banjar house $10 \mathrm{~m}=$ $425.000 \rightarrow 1 \mathrm{~m}=425.000 \div 10=42.500$ and the price of the sasirangan fabric with the hiris gegatas motif and the flower sasaki $9 \frac{1}{4} \mathrm{~m}=$ $578.125 \rightarrow 1 m=578.125 \div 9,25=62.500$. Then what was asked from the question, namely the price of $8 \mathrm{~m}$ of Banjar house motif fabric, the price of $6 \frac{3}{4} \mathrm{~m}$ of sasirangan fabric with hiris gagatas and flower sasaki motifs and is it true that the price of $1 \mathrm{~m}$ of sasirangan fabric with Banjar motifs and $1 \mathrm{~m}$ of sasirangan fabric with hiris gagatas and flower sasaki motifs is 65,000? Thus, in the activity of understanding the problem, it can be seen that APP is able to understand the problem of the HOTS problem given but has not been careful to determine what is being asked.

2. M2 (Planning The Problem)

APP does not develop a strategy to answer what is known and asked from the questions at the stage of planning the problem. Based on APP's answer sheet, APP did not plan what to look for in advance.

3. M3 (carrying out the plan)

At the stage of implementing the plan, APP immediately carried out the calculations, namely APP multiplied the price of $1 \mathrm{~m}$ of Banjar house motif cloth obtained to find out how much $8 \mathrm{~m}$ of sasirangan fabric with Banjar motif of $8 \times$ $42,500=340,000$ and APP multiplied the price of $1 \mathrm{~m}$ of sasirangan fabric with hiris gagatas and flower sasaki motifs obtained to find out how much the $6 \frac{3}{4} \mathrm{~m}$ Sasirangan fabric with hiris gagatas and flower sasaki motifs costs $6.75 \times$ $62.500=421.875$. However, APP did not verify the price of $2 \mathrm{~m}$ of sasirangan fabric with the motif of a Banjar house and $1 \mathrm{~m}$ of sasirangan fabric with the motifs of hiris gagatas and flower sasaki. In point (b), this APP only states that the statement in point (b) is not true.

4. M4 (Looking Back)

APP does not write conclusions from the solutions and problems in the HOTS problems given at re-checking the truth that APP has done. And the APP doesn't do the recalculation differently. According to Polya, the analysis of written answers shows that APP can bring up several stages of problem-solving, namely understanding the problem and implementing the plan.

Therefore, to explore APP ability to solve HOTS problems, interviews were conducted between researchers and APP, which are described below:

$\mathrm{P} \quad$ : After you read the questions given. Do you understand the matter?

APP : Yes, ma'am.Iya bu.

$\mathrm{P}$ : After you read and understand the questions given. What do you know from the questions given?

APP : Is known from the question is the price of the sasirangan fabric with the motif of the Banjar house $10 \mathrm{~m}=425,000$ and the price of the sasirangan fabric with the hiris gegatas and flower sasaki motifs $91 / 4 \mathrm{~m}=578,125$.

$\mathrm{P} \quad$ : Then what is asked in the given question?

APP : What is being asked about is the price of $8 \mathrm{~m}$ of Banjar house motif, $6 \frac{3}{4} \mathrm{~m}$ of sasirangan cloth with hiris gegatas and flower motifs of sasaki, and is it true that the price of $1 \mathrm{~m}$ of sasirangan cloth with Banjar motif and $1 \mathrm{~m}$ of sasirangan cloth with hiris gegatas and flower motifs of sasaki.

$\mathrm{P} \quad$ : Try to reread the questions given. What was asked? Is what is written in accordance with what is in the question?

APP : sorry ma'am, for what I asked, I was not careful in reading.

$\mathrm{P} \quad$ : How do you plan to solve the problems given?

APP : I didn't write down the strategy or plan to solve the given problem, but I immediately finished the given question.

$\mathrm{P} \quad$ : Are you sure about the answers you have done?

APP : Insya Allah, Are you sure ma'am.

$\mathrm{P} \quad$ : Based on the solutions you got, did you make any conclusions from the results you have done?

APP : I did not re-check the steps that have been taken, and I did not write down the 
conclusions of the solutions and problems in the questions.

Based on the results of student answers and interviews, it can be concluded that students who have low mathematical abilities are less able to solve HOTS problems. At the Polya problem-solving ability stage, the subject can apply several Polya stages, namely understanding problems and making plans. However, they are less able to make plans, so the subject is less able to carry out plans and Looking Back.

\section{DISCUSSION}

When viewed from the results that have been presented, overall, the subjects have the highest cognitive level differences in solving HOTS problems.

\subsection{Students who have a High level of Mathematical Ability (SFZ)}

Based on the results of the analysis of student answer sheets and interviews, information was obtained that students who have a high level of mathematical ability, namely SFZ, can reach the highest cognitive level of C6, namely creating and SFZ fulfils every indicator of mathematical problem solving, namely SFZ can understand the problem by writing down what is known and what is asked in the questions, SFZ also plans problems by writing down the steps he will take first to solve the given HOTS problem, SFZ can carry out the plan according to what he has planned, SFZ re-examines the answers he has worked on by writing conclusions that are in accordance with the questions given and SFZ also reproves by using a different way, namely using comparisons. HOTS-capable students at the stage of creating are students who can design questions and make new steps [29]. SFZ can solve problems, conclude at the end of the answer, and work in different ways. SFZ can meet all the HOTS indicators, namely analyzing, evaluating and creating correctly and correctly so that SFZ is the student who reaches the highest cognitive level of HOTS. Students who have the HOTS ability are students who can analyze, evaluate and create [30].

\subsection{Students who have a Medium level of Mathematical Ability (BD)}

Based on analysis of the students' answer sheets and interviews, students who have high levels of mathematical ability Medium, namely BD, can reach the level of cognitive C5 ( Evaluating ). BD does not meet all the indicators solving mathematical problems, $\mathrm{BD}$ is only able to meet the two hands solving mathematical problems, namely understanding the problem and implementing the plan. The students' HOTS abilities can be seen from their abilities when posing and solving given problems. Because there are indicators that BD has not achieved, namely the indicator of creating BD has not been able to formulate stage and BD cannot find new solutions in solving the given problem, so BD is included in the students who have the highest cognitive level C5 (evaluating).

\subsection{Students who have a Low level of Mathematical Ability (APP)}

Based on the results of the analysis of student answer sheets and interviews that have been carried out, information is obtained that students who have a low level of mathematical ability, namely APP, can reach cognitive level C4 (analyze). APP does not meet all indicators of mathematical problem solving, APP can only complete two hands of solving mathematical problems, namely understanding the problem and implementing the plan, because APP does not meet the two HOTS indicators, namely evaluating and creating. Students who are said to have HOTS abilities are students who can analyze, assess and make in solving problems [30]. So that APP is included in the students who reach the highest cognitive level C4 (Analyzing).

\section{CONCLUSION}

Based on the results of the research and discussion that have been described, it can be concluded that each subject has a different HOTS cognitive level in solving HOTS problems, where students with high mathematical abilities can solve HOTS problems up to the C6 cognitive level, which can meet all indicators of analyzing, evaluate and create, and be able to solve HOTS problems according to the indicators of mathematical problem solving according to polya, namely understanding the problem, planning the problem, implementing the plan and checking again. For students with moderate mathematical ability, are able to solve HOTS problems up to the C5 cognitive level, which is to analyze and evaluate but do not meet all indicators of mathematical problem solving according to polya and can only meet two indicators of mathematical problem solving, namely understanding the problem and implementing the plan. Students with low mathematical ability only meet one HOTS indicator, namely analyzing, and can only complete two indicators of mathematical problemsolving ability according to Polya, namely understanding problems and implementing plans, so that they only reach the $\mathrm{C} 4$ cognitive level, namely analyzing indicators.

Research results can be used as a theoretical guide for future research. Subsequent research can focus on 
how to provide assistance to students in solving HOTS problems in terms of the stages of solving Polya problems and from other perspectives. Similar research can also be developed in other materials and at different levels of education, considering that HOTS has an essential role for students in the 21 st century

\section{ACKNOWLEDGMENTS}

The author would like to thank the Master of Mathematics Education Study Program, Faculty of Teacher Training and Education, Sebelas Maret University. And the author would like to thank MtsN 9 Banjar and all research subjects which have helped in the smooth running of the research.

\section{REFERENCES}

[1] N. L. Utami, "Higher Order Thinking Skill: Teachers' Perception and Their Assessment Implementation," Ling. J. Bhs. dan Sastra, vol. 20, 2020.

[2] G. Angraini and S. Sriyati, "Analisis Kemampuan Berpikir Tingkat Tinggi Siswa SMAN Kelas X Di Kota Solok Pada Konten Biologi," Angraini, Gustia Sriyati, Siti, vol. 1, no. 1, p. 124, 2019.

[3] G. S. Pratama and H. Retnawati, "Urgency of Higher Order Thinking Skills (HOTS) Content Analysis in Mathematics Textbook," J. Phys. Conf. Ser., vol. 1097, no. 1, 2018, doi: 10.1088/1742-6596/1097/1/012147.

[4] Y. M. Heong, W. B. Othman, J. B. M. Yunos, T. T. Kiong, R. Bin Hassan, and M. M. B. Mohamad, "The Level of Marzano Higher Order Thinking Skillsamong Technical Education Students," Int. J. Soc. Sci. Humanit., vol. 1, no. 2, p. 121, 2011, doi: 10.7763/ijssh.2011.v1.20.

[5] Winarni, "Peningkatan Kemampuan Berpikir Tingkat Tinggi Menggunakan Huruf Kapital melalui Penerapan Model PJBL di Sdit Izzatul Islam Getasan," J. Manaj. Pendidik., vol. 14, no. 1, pp. 18-24, 2019.

[6] E. Yayuk, Purwanto, A. R. As'Ari, and Subanji, "Primary school students' creative thinking skills in mathematics problem solving," Eur. J. Educ. Res., vol. 9, no. 3, pp. 1281-1295, 2020, doi: 10.12973/eujer.9.3.1281.

[7] A. H. Wahid and R. A. Karimah, "Integrasi High Order Thinking Skill (HOTS) dengan Model Creative Problem Solving," Model. J. Progr. Stud. PGMI, vol. 5, no. 1, p. 88, 2018.
[8] M. Z. Fanani, "Strategi Pengembangan Soal Hots Pada Kurikulum 2013," Edudeena, vol. 2, no. 1 , p. $60,2018$.

[9] L. W. Anderson et al., A Taxonomy for Learning Teaching And Assessing : a Revision of Bloom's Taxonomy of Educational Objectives. New York: Longman, 2001.

[10] S. Hadi, "Junior High School Student's Ability To Complete Mathematical HOTS Questions," J. Ilm. Glob. Educ., vol. 1, no. 2, p. 1,2020

[11] Jailani dkk, Desain Pembelajaran Matematika : untuk melatihkan Higher Order Thinking Skills. Yogyakarta: UNY Press, 2018.

[12] W. S. Lilik Ayumniyya, "Profil Kemampuan Berpikir Tingkat Tinggi Siswa SMA Dalam Pemecahan Masalah Pada Materi Hukum Newton," IPF Inov. Pendidika Fis., vol. 10, no. 1, p. 51, 2021.

[13] P. Amalia, "Development of Learning Materials Based on Problem Based Learning to Improve Students Problem Solving Ability," Annu. Int. Semin. Transform. Educ. Educ. Leadersh., vol. 4, pp. 221-225, 2019.

[14] A. R. Asari, U. N. Malang, and J. Timur, "Optimizing Problem Solving Activity for Teaching Thinking Optimizing Problem Solving Activity For Teaching Mathematical Thinking Consider the folowing simple combinatoric problem: " How many rectangles are there in," Int. Semin. Math. Educ. UNISMA, 2015, doi: 10.13140/2.1.2437.8409.

[15] N. Nurkaeti, "Polya'S Strategy: an Analysis of Mathematical Problem Solving Difficulty in 5Th Grade Elementary School," EduHumaniora | J. Pendidik. Dasar Kampus Cibiru, vol. 10, no. 2, p. 140, 2018, doi: 10.17509/eh.v10i2.10868.

[16] Z. A. Alfika and T. Mayasari, "Profil Kemampuan Memecahkan Masalah Pelajaran Fisika Siswa MTs," Pros. Semin. Nas. Quantum, vol. 25, p. 584, 2018.

[17] G. Polya, How To Solve It, 2nd ed. New Jersey: Princeton University Press, 1985.

[18] D. Purba, Z. Nasution, and R. Lubis, "Pemikiran George Polya Tentang Pemecahan Masalah," ... (Mathematic Educ. Journal), vol. 4, no. 1, p. 27, 2021. 
[19] E. Mahardhikawati, Mardiyana, and R. Setiawan, "Analisis Kemampuan Pemecahan Masalah Berdasarkan Langkah-Langkah Polya pada Materi Turunan Fungsi Ditinjau dari Kecerdasan Logis-Matematis Siswa Kelas XI IPA SMA Negeri 7 Surakarta Tahun Ajaran 2013/2014," J. Pendidik. Mat. dan Mat. Solusi, vol. 1, no. 4, pp. 120-121, 2017.

[20] C. Alacaci and M. Dogruel, "Solving a Stability Problem By Polya'S Four Steps," Int. J. Electron. Mech. Mechatronics Eng., vol. 1, no. 1, pp. 19-28, 2012.

[21] D. Haryani, "Pembelajaran Matematika Dengan Pemecahan Masalah Untuk Menumbuhkembangkan Kemampuan Berpikir Kritis Siswa," Pros. Semin. Nas. Penelitian, Pendidik. dan Penerapan MIPA, Fak. MIPA, Univ. Negeri Yogyakarta, no. 1980, pp. 121-126, 2011.

[22] E. Apino and Retnawati, "Developing Instructional Design to Improve Mathematical Higher Order Thinking Skills of Students," J. Phys. Conf. Ser., 2017, doi: 10.1088/17426596/812/1/012100.

[23] J. W. Cresswell, Educational Research: Planning, Conducting, and Evaluating Quantitative and Qualitative Research, 4th ed. United State of America: Pearson, 2012.

[24] M. N. Kholid, C. Sa'dijah, E. Hidayanto, and H. Permadi, "How are students' reflective thinking for problem solving?," J. Educ. Gift. Young Sci., vol. 8, no. 3, pp. 1135-1146, 2020.

[25] Sugiyono, Metode Penelitian Kuantitatif, Kualitatif dan $R \& D$. Bandung: Alfabeta, 2016.

[26] S. Arikunto, Dasar-dasar Evaluasi Pendidikan Edisi 3, 3rd ed. Jakarta: PT. Bumi Aksara, 2021.

[27] M. B. Miles, A. M. Huberman, and J. Saldana, A Methods Sourcebook: Qualitative Data Analysis Third Edition. United State of America: Sage Publications, 2014.

[28] M. N. Kholid, A. Imawati, A. Swastika, S. Maharani, and L. N. Pradana, "How are Students' Conceptual Understanding for Solving Mathematical Problem?," J. Phys. Conf. Ser., vol. 1776, no. 1, 2021, doi: 10.1088/1742-6596/1776/1/012018.

[29] D. Kurniati, R. Harimukti, and N. A. Jamil, "Kemampuan berpikir tingkat tinggi siswa
SMP di Kabupaten Jember dalam menyelesaikan soal berstandar PISA," $J$. Penelit. dan Eval. Pendidik., vol. 20, no. 2, p. 153, 2016, doi: 10.21831/pep.v20i2.8058.

[30] R. Arifin Nugroho, High Order Thinking Skills. Jakarta: Gramedia Widiasarana Indonesia, 2018. 